\title{
Effects of gamma irradiation on the shelf-life of frozen tiger shrimp, Penaeus monodon (Fabricius, 1798)
}

\author{
Mustafa MG ${ }^{1}$, Hossain MA ${ }^{1}$, Alam MJ ${ }^{1 *}$, Khan MMR ${ }^{1}$, Nilla $S^{1}{ }^{1}$ and Alam MZ \\ ${ }^{1}$ Department of Fisheries, University of Dhaka, Dhaka 1000 \\ ${ }^{2}$ Food Processing and Preservation Division, Institute of Food and Radiation Biology, Atomic Energy \\ Commission, Savar, Dhaka
}

[Received: January 18, Accepted: May 19, 2014]

\begin{abstract}
The effects of three levels of irradiation (3, 6 and $9 \mathrm{KGy})$ during storage period $(0,15,30,45,60,75$ and 90 days) were evaluated in frozen tiger shrimp, Penaeus monodon. Biochemical composition was analyzed before and after treatment. Quality of tiger shrimp was assessed through organoleptic, chemical (Total Volatile Nitrogen, TVN and Trimethylamine, TMA) and microbiological (Total Bacterial Count (TBC); Total Mold Counts (TMC); Total Yeast Count, (TYC); Total Coliform Count, (TCC) and Salmonella count) evaluation at an interval of 15 days during the storage period. High doses of radiation affected on the texture of fish. While, the maximum shelf life was observed for 9 KGy irradiated sample. All the samples were acceptable during 90 days of storage period because the upper limit of all spoilage indicators did not exceed the recommended values.
\end{abstract}

Key Words: Food acceptability, microbial flora, frozen temperature, gamma radiation, Penaeus monodon

\section{INTRODUCTION}

In Bangladesh, shrimp and fish are frequently sold and preserved at traders and consumers level in icing or, freezing condition. It concerns with animal protein derived from marketed fish, fishery products, meats and meat products that creates a high risk commodity regarding to pathogenic/ microbial contaminations, adulterants and natural toxicity causes death ${ }^{[1]}$. Bacteriological quality of fish concerns to the spoilage and in some cases creates chance for the outbreak of food poisoning ${ }^{[2]}$. Besides, anthropogenic and biological contagions depreciate the water quality of the shrimp farming area which cause great difficulties in shrimp exporting with the international quality standard. Shrimps, exported principally to USA, Japan and Europe from Bangladesh ${ }^{[3]}$, is threatened for low quality of processed shrimp products due to small size, bacterial load or presence of chemical residue levels ${ }^{[1,2]}$. Raw or frozen shrimp deteriorated by improper handling are responsible for causing foodborne diseases ${ }^{[1]}$ and diseases transmission. Poor quality of the raw material and poor sanitary performance of freezing plant and also the freezing of decomposed shrimps are major problems encountered by the seafood industry.

Spoilage due to microbial activity is the main limitation of the shelf life of refrigerated fish ${ }^{[4]}$. By lowering or raising the temperature, bacteria and autolytic spoilage rate can be reduced ${ }^{[5]}$. Refrigeration inhibits the activity of food spoilage organisms and the low storage temperature greatly slows down the enzymatic and biochemical reactions that normally occur in unfrozen foods ${ }^{[6]}$. Besides, food irradiation is a process exposing food to ionizing such as gamma rays emitted from radioisotopes ${ }^{60} \mathrm{Co} 27$ and ${ }^{137} \mathrm{Cs} 55$ or high energy electrons and $\mathrm{X}$-rays produced by machine sources [7]. Depending on the absorbed radiation dose, various effects can be achieved resulting in reduced storage losses, extended shelf life and/ or improved micro biological and parasitological safety of foods. The interest in food irradiation is fast growing both in developed and developing countries. International bodies such as International Atomic Energy Agency (IAEA), Food and Agricultural Organization (FAO) and World Health Organization (WHO) are now actively engaged in bringing out recommendations for facilitating the acceptance of food irradiation processes, by all United Nations (UN) member states. Food irradiation ensures better public health and offers greater economic advantage to the producers in developing countries.

Since, tiger shrimp (Penaeus monodon), one of the exported commodities, is a valuable source of foreign currency. So, its shelf life extension is very much crucial. But, lack of proper techniques of preservation a significant amount of shrimps and prawns have been destroyed every year ${ }^{[1,2]}$. So, inquest of a new and pertinent technology of preservation is essential to protect the national loss. Various factors contribute to the spoilage and deterioration in the quality of the products.

The main purpose of the present study was to determine the quality of frozen exportable tiger shrimp using different doses of gamma irradiation as well as the microbiological, chemical and organoleptic scores in the control and different irradiated samples stored at $-20^{\circ} \mathrm{C}$. 


\section{MATERIALS AND METHODS}

\section{Experimental specimen and sampling}

Tiger shrimp, Penaeus monodon (Fabricius, 1798) locally known as 'Bagda Chingri', was considered as an experimental specimen for this study. The specimen tiger shrimp, $P$. monodon at $-20^{\circ} \mathrm{C}$ was collected from Snow King Frozen Foods (pvt.) Ltd., Mirpur, a fish processing factory of Dhaka, where the factory authority collected the shrimp from Rupsa, Khulna. Collected blocked shrimp was immediately transferred to pre-sterilize polythene bag and carried to the laboratory of Food Processing and Preservation Division, Institute of Food and Radiation Biology (IFRB), Atomic Energy and Research Establishment (AERE), Savar, Dhaka, Bangladesh for analysis.

\section{Research and sampling design}

The present study has symmetrically done for biochemical composition and quality assessment of tiger shrimp. The entire samples were at first randomly grouped into four lots for biochemical, microbiological and nutritional studies. The four lots were taken in four polypropyl polythene bags for preservation purposes under control and 3, 6, 9 KGy doses of gamma irradiation. Therefore, shrimps were divided into the following treatment groups Treatment A: Control (without irradiation), Treatment B: Irradiated (3 KGy), Treatment C: Irradiated (6 KGy), Treatment D: Irradiated (9 KGy). Treatment A was kept at $-20^{\circ} \mathrm{C}$ without irradiation. Treatment $\mathrm{B}, \mathrm{C}$ and $\mathrm{D}$ were subjected to irradiation in 3, 6 and $9 \mathrm{KGy}$ with a panoramic ${ }^{60} \mathrm{Co}$ source supplied by the Atomic Energy of Canada Ltd. After irradiation, the irradiated treatment $\mathrm{B}, \mathrm{C}$ and $\mathrm{D}$ were kept at $-20^{\circ} \mathrm{C}$. All treatments were considered for biochemical and microbiological analysis at the 0 , $15,30,45,60,75$ and 90 days of storage period. The data were taken at an interval of 15 days up to 90 days during the storage periods. each sample was taken and homogenized in mortar and pastel to prepare sample. Sterilization media (Nutrient agar media for TBC, PDA media for TMC and Yeast media) were used for microbial analysis ${ }^{[12]}$. Dehydrated nutrient agar (Difco) consisting of peptone was used as the media for the bacterial growth and potato dextrose agar media was used for the mold growth. Yeast extract media was used for yeast growth and SS media used for Salmonella count. Colonies that developed on the plates after incubation at $37^{\circ} \mathrm{C}$ and $30^{\circ} \mathrm{C}$ after 24 and 48 hours were counted with the help of colony counter. The number of bacterial, mold, yeast, coliform and Salmonella colonies was obtained by standard method and expressed as cfu/g ${ }^{[12]}$.

\section{Data analysis}

Statistical analyses were performed among the various content of bio-chemical compositions as well as in between treatments and storage periods on various quality evaluation indices with the SPSS software package (verson11.5, SAS Institute Inc, USA) to present the data as mean \pm SEM.

\section{RESULTS AND DISCUSSION}

Moisture, protein, lipid, ash and mineral (calcium and phosphorus) contents of $P$. monodon are presented in Table 3 where the major constituent of tiger shrimp was moisture. Average moisture content was $78.45 \pm 0.26 \%$ that agreed with the findings of Khan et al. ${ }^{[13]}$, Akintola et al. ${ }^{[14]}$, Nisa and Sultana $^{[15]}$, NIN ${ }^{[16]}$, Begum and Hoque ${ }^{[17]}$, Aykroyed et al. ${ }^{[18]}$ in shrimps and Ferdose and Hossain ${ }^{[19]}$ in prawn (Macrobrachium rosenbergii). On the other hand, a little bit less amount of moisture than that of the present study were reported by Abdel-Salam ${ }^{[20]}$, Shalini et al. ${ }^{[21]}$, Puga-López et al. ${ }^{[22]}$ in shrimp. The protein content of tiger shrimp is also a focal point, average protein content was $18.45 \pm 0.3 \%$ in $P$. monodon. Similar results were also found by Khan $e t$

Table 1. Mean ( \pm SEM) biochemical composition of frozen Penaeus monodon.

\begin{tabular}{cccccc}
\hline $\begin{array}{c}\text { Moisture } \\
(\%)\end{array}$ & $\begin{array}{c}\text { Protein } \\
(\%)\end{array}$ & $\begin{array}{c}\text { Lipid } \\
(\%)\end{array}$ & $\begin{array}{c}\text { Ash } \\
(\%)\end{array}$ & $\begin{array}{c}\text { Calcium } \\
(\mathrm{mg} / 100 \mathrm{~g})\end{array}$ & $\begin{array}{c}\text { Phosphorus } \\
\mathrm{mg} / 100 \mathrm{~g})\end{array}$ \\
\hline $78.45 \pm 0.26$ & $18.45 \pm 0.30$ & $1.73 \pm 0.04$ & $1.12 \pm 0.03$ & $210.78 \pm 6.90$ & $102.80 \pm 7.10$ \\
\hline
\end{tabular}

\section{Laboratory assay}

All samples were examined for proximate composition according to $\mathrm{AOAC}^{[8]}$. The stored samples were evaluated organoleptically for odor, appearance, color and texture by a panel of judges on a 9 point hedonic scale as described by Peryam and Pilgram ${ }^{[9]}$. Trimethylamine (TMA) and Total Volatile Nitrogen (TVN) were examined by using Conway micro diffusion technique method ${ }^{[10]}$.

The Total Bacterial Count (TBC), Total Mould Count (TMC) and Total Yeast Count (TYC) were estimated by the method described by Sharf ${ }^{[11]}$ using pour plate technique. Two (2) g shrimp muscle of $a l .{ }^{[13]}$ as $18.41 \pm 0.54 \%$ protein in Metapenaeus monoceros, Nisa and Sultana ${ }^{[15]}$ as $19.00 \%$ in muscle of matured Fenneropenaeus penicillatus, Begum and Hoque $^{[17]}$ found $17.35 \%$ protein; Aykroyed et al.$^{[18]}$ and $\mathrm{NIN}^{[16]}$ were recorded $19.1 \%$ protein in shrimps that were quite similar with the present findings. But Puga-López et al. ${ }^{[22]}$ reported $20.04 \pm 0.93 \%$ and $20.47 \pm 0.61 \%$ protein in Litopenaeus vannamei and L. stylirostris, respectively; and Shalini et al..$^{[21]}$ recorded higher $25.01 \pm 0.02 \%$ and $22.17 \pm 0.02 \%$ in tissues of $L$. vannamei and $F$. indicus, respectively. On the contrary, Abdel-Salam ${ }^{[20]}$ found $42.88 \pm$ $1.11 \%$ and $40.68 \pm 2.28 \%$ in male and female $P$. 
indicus, respectively and Akintola et al. ${ }^{[14]}$ estimated $64.74 \pm 0.45 \%$ in fresh $P$. monodon in dry weight basis.

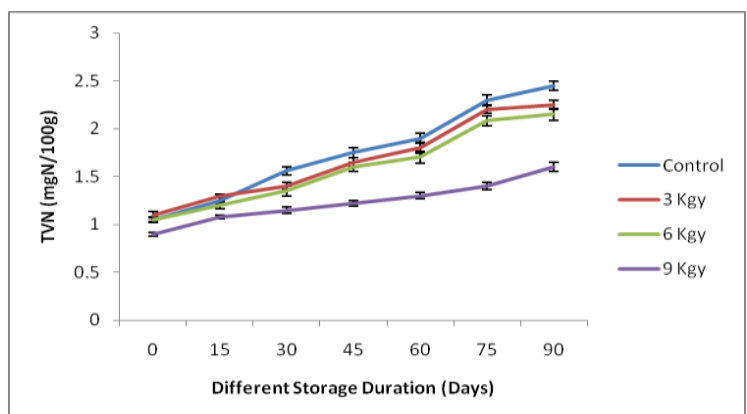

Fig. 1. Mean ( \pm SEM) TVN values $\left(\mathrm{cfug}^{-1}\right)$ of Penaeus monodon during 90 days of storage period at $-20^{\circ} \mathrm{C}$ with control and different doses of radiation treatments.

There is no significant difference in lipid content of treated shrimp samples. Average fat content was 1.73 $\pm 0.04 \%$ that was similar with the findings of Begum and Hoque ${ }^{[17]}$ in shrimps $(1.68 \%)$, Nisa and Sultana $^{[15]}(1.5 \%)$ in muscle of matured $F$. penicillatus, Puga-López et al. ${ }^{[22]}(1.27 \pm 0.16 \%$ and $1.03 \pm 0.15 \%$, respectively) in $L$. vannamei and $L$. stylirostris; and also the findings $(1.65 \%)$ by $\mathrm{NIN}^{[16]}$ and Aykroyed et al. ${ }^{[18]}$ in shrimps. The results of Khan et al. ${ }^{[13]}(2.84 \pm 0.42 \%)$ in $M$. monoceros, Shalini et al. ${ }^{[21]}(2.13 \pm 0.02 \%$ and $0.01 \pm 0.02 \%$, respectively) in tissues of $F$. indicus and L. vannamei also support the present finding. But Akintola et $a l .{ }^{[14]}$ recorded higher $(4.88 \pm 0.04 \%)$ lipid in $P$. monodon in dry weight basis and Abdel-Salam ${ }^{[20]}$ reported quite higher $8.57 \pm 0.24$ and $8.92 \pm 0.02 \%$ in male and female $P$. indicus, respectively than that of the present finding. In the present investigation, average ash content was $1.12 \pm 0.03 \%$ of shrimp that was paralleled with the judgment of Khan et al. ${ }^{[13]}$ $(1.31 \pm 0.14 \%)$ in $M$. monoceros, Nisa and Sultana ${ }^{[15]}$ $(1.86 \%)$ in muscle of matured $F$. penicillatus and $\mathrm{NIN}^{[16]}$ in shrimps. However, Begum and Hoque ${ }^{[17]}$ found $2.60 \%$ ash in shrimp, Puga-López et al. ${ }^{[22]}$ recorded higher ash content $(2.26 \pm 1.66 \%$ and 2.30 $\pm 0.71 \%)$ in $L$. vannamei and L. stylirostris, respectively; Akintola et al. ${ }^{[14]}$ estimated $12.66 \pm$ $0.17 \%$ in $P$. monodon (in dry weight basis) than that of the present one.

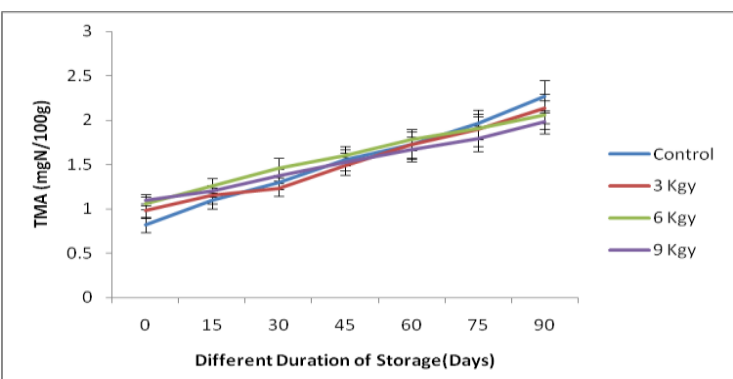

Fig. 2. Mean ( \pm SEM) TMA values $\left(\mathrm{cfug}^{-1}\right)$ of frozen (at $-20^{\circ} \mathrm{C}$ ) Penaeus monodon with control and different doses of radiation treatments during 90 days of storage period.
Nurullah et al. ${ }^{[23]}$ reported that the average moisture content of fish increased during freezing, whereas protein, lipid and ash reduced in fresh condition. As fat deposition and moisture have inverse relationship ${ }^{[4,7]}$, greater percentage of moisture was observed in shrimp. Similar inverse relation between fat and moisture content was also recorded by Mustafa et al. ${ }^{[7]}$, Sayed et al. ${ }^{[4]}$ and Chakraborty et $a l .^{[24]}$ for different fish during gamma irradiation at low temperature. The body composition seems to depend on age, sex, seasons ${ }^{[4]}$, size, temperature, stages of maturity, and $\operatorname{diet}^{[25]}$ and varies from species to species and even within the same species from one individual to another. The composition varies with season, size, stages of maturity, temperature and deviation may occur due to natural feeding habits and availability of feed, fasting duration during spawning and migration ${ }^{[23]}$.

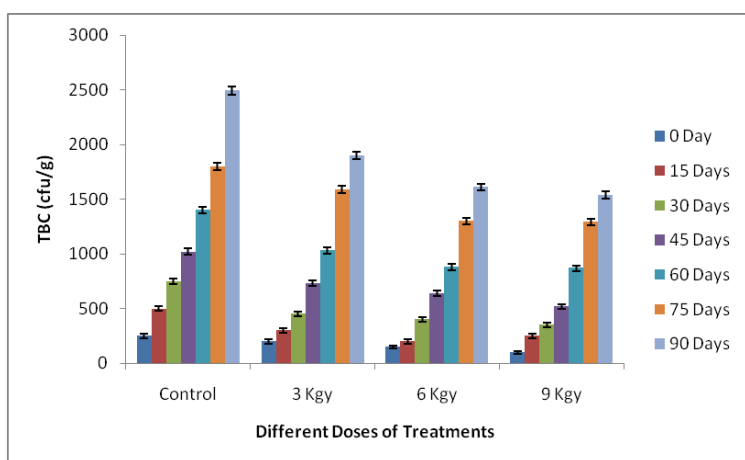

Fig. 3. Mean ( \pm SEM) TBC values in $\operatorname{cfug}^{-1}$ of irradiated frozen $\left(\right.$ at $\left.-20^{\circ} \mathrm{C}\right)$ Penaeus monodon sampled from control and different doses treatments at different storage period.

In the present study, average calcium $(\mathrm{Ca})$ content was $210.78 \pm 6.90 \mathrm{mg} / 100 \mathrm{~g}$ of shrimp muscle. Similar Ca content was recorded by Shalini et al. ${ }^{[21]}$ as $279.00 \pm 0.03$ and $273.30 \pm 5.73 \mathrm{mg} / 100 \mathrm{~g}$ in tissues of $L$. vannamei and $F$. indicus, respectively. But Abdel-Salam ${ }^{[20]}$ found $45.09 \pm 1.30$ and $39.96 \pm$ $2.20 \mathrm{mg} / 100 \mathrm{~g} \mathrm{Ca}$ in edible muscle of male and female $P$. indicus, respectively; and Begum and Hoque $^{[17]}$ reported $114.65 \mathrm{mg} / 100 \mathrm{~g}$ of $\mathrm{Ca}$ in shrimp which are lower than the present finding, whereas $\mathrm{NIN}^{[16]}$ estimated $323 \mathrm{mg} / 100 \mathrm{~g}$ of calcium in shrimp which is higher than the present result. In the present research, average phosphorus $(\mathrm{P})$ content was 102.80 $\pm 7.1 \mathrm{mg} / 100 \mathrm{~g}$ of shrimp muscle. Abdel-Salam ${ }^{[20]}$ found more less $\mathrm{P}$ content $(74.32 \pm 1.99$ and $75.45 \pm$ $1.78 \mathrm{mg} / 100 \mathrm{~g}$ in male and female $P$. indicus, respectively) in edible muscle than the present finding. On the other hand, Shalini et al. ${ }^{[21]}$ reported $215.06 \pm 0.02$ and $251.39 \pm 0.53 \mathrm{mg} / 100 \mathrm{~g} \mathrm{P}$ in tissues of $L$. vannamei and $F$. indicus, respectively; and $\mathrm{NIN}^{[16]}$ estimated $278 \mathrm{mg} / 100 \mathrm{~g}$ of phosphorus in shrimp which are higher than the present result (Table 1).

The highest organoleptic score (OS) was found in the $6 \mathrm{KGy}$ treatment group, whereas the lowest score was measured in the control group. Among durations 
and treatments scores were significantly different. Under the investigation, best result of OS was found in the treatment of $6 \mathrm{KGy}$ (Table 2). The treated samples with $6 \mathrm{KGy}$ were better organoleptically than those with $9 \mathrm{KGy}$. It might be the high dosage of irradiation damages the texture. Similar trend was found by Sayed et al..$^{[4]}$ and Ahmed et al. ${ }^{[26]}$ in fish during irradiation at low temperature. It was clear that with the increase of storage period the OS were rapidly decreased in the control shrimps than those irradiated shrimps at different doses. Besides, the sub-tropical environment might also be the crucial reason for the presence of different types of bacteria in fishes might be the reason to spoilage as well as acceptability ${ }^{[1,2]}$. Due to microbial spoilage with the increase of storage period, the appearance, odor, color and texture will also be deteriorated ${ }^{[4,7]}$, therefore the OS were decreased.

Regarding the biochemical parameters, the best result of TVN value was found at the treatment dose of 9 KGy (Fig. 1) and the TVN values gradually increased with the progress of storage periods. During the storage period of 90 days, the TVN value of all the samples was comparatively lower in $9 \mathrm{KGy}$
The TMA values were gradually increased with the progress of storage period (Fig. 2). Comparing the TMA values, the lowest value was found in 9 KGy treatment group while the highest value was measured in the control group. The TMA value of 3 KGy and $6 \mathrm{KGy}$ treatments were also different. Among the durations and the treatments, the values were significantly different. Under this investigation, best result of TMA value was found for $9 \mathrm{KGy}$. The production of TMA was retarded considerably in the irradiated samples as compared to the controlled samples. Such pattern was also obtained from the observations of Mustafa et al. ${ }^{[7]}$, Sayed et al..$^{[4]}$, Chakraborty et al. ${ }^{[24]}$, Ahmed et al. ${ }^{[26]}$. Suppression of TMA accumulation in the irradiated samples indicated that micro flora was capable of producing TMA were probably selectively removed by irradiation $^{[26]}$. So, the effect of irradiation was well effective in the rate of TMA accumulation ${ }^{[6]}$.

The TBC during different storage period presented in Fig. 3 for $P$. monodon illustrated that at the beginning of 90 days storage period bacterial growth were affected by the radiation and differs significantly. The results showed that bacterial

Table 2. Organoleptic score (mean \pm SEM) obtained from control and different irradiation treatments of frozen Penaeus monodon during 90 days storage period at $-20^{\circ} \mathrm{C}$.

\begin{tabular}{ccccc}
\hline \multirow{2}{*}{ Duration (day) } & \multicolumn{3}{c}{ Level of Radiation (KGy) } \\
\cline { 2 - 4 } Control & $9.00 \pm 0.00$ & $9.00 \pm 0.00$ & $6.00 \pm 0.00$ & $9.00 \pm 0.00$ \\
15 & $8.25 \pm 0.05$ & $8.55 \pm 0.10$ & $8.60 \pm 0.05$ & $8.80 \pm 0.05$ \\
30 & $8.00 \pm 0.15$ & $8.10 \pm 0.01$ & $8.18 \pm 0.02$ & $8.37 \pm 0.07$ \\
45 & $7.45 \pm 0.05$ & $7.75 \pm 0.05$ & $8.13 \pm 0.03$ & $8.03 \pm 0.03$ \\
60 & $7.05 \pm 0.10$ & $7.35 \pm 0.10$ & $7.68 \pm 0.03$ & $7.18 \pm 0.08$ \\
75 & $6.55 \pm 0.20$ & $6.95 \pm 0.10$ & $7.28 \pm 0.07$ & $6.90 \pm 0.05$ \\
90 & $6.00 \pm 0.15$ & $6.75 \pm 0.05$ & $7.07 \pm 0.04$ & $6.58 \pm 0.07$ \\
\hline
\end{tabular}

treated storage of the experiments due to retardation of enzymatic action at higher irradiation ${ }^{[4,7]}$. Among durations and treatments, the values were significantly different. Increased value of TVN decreased the acceptability of fish. Such pattern of result was also obtained from the observations of Sayed et al. ${ }^{[4]}$, Mustafa et al. ${ }^{[7]}$, Chakraborty et al. ${ }^{[24]}$ and Ahmed et al. ${ }^{[26]}$.

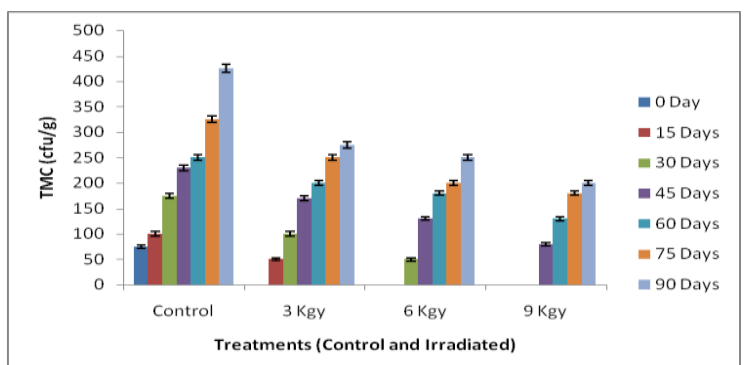

Fig. 4. Mean ( \pm SEM) TMC $\left(\mathrm{cfug}^{-1}\right)$ values of Penaeus monodon during 90 days of storage period at $-20^{\circ} \mathrm{C}$ with control and different doses of treatments. counts were increased rapidly under controlled but slowly in $9 \mathrm{KGy}$ treated samples. Similar trend was also found from the observations of Sayed et al. ${ }^{[6]}$, Mustafa et al. ${ }^{[7]}$, Chakraborty et al. ${ }^{[24]}$, Ahmed et $a l .{ }^{[26]}$, Haque et al. ${ }^{[27]}$ for freshwater fish and Hossain et al. ${ }^{[28]}$ for marine fish. The lowest value of TBC was found in $9 \mathrm{KGy}$ treated group, while the highest value was measured in the control group. The TBC of $3 \mathrm{KGy}$ and $6 \mathrm{KGy}$ treatments were also different. Irradiated samples remained acceptable according to $\mathrm{ICMSF}^{[29]}$ up to 90 days of storage period (Fig. 3 ). To detect the days when level of TBC exceed the acceptable limit research should be conducted for long time. The TMC value $\left(\mathrm{cfug}^{-1}\right)$ was also affected by different doses of irradiation. The lowest value was found in the $9 \mathrm{KGy}$ treatment group, while the highest value was measured in the control group (Fig. 4). Among the durations and the treatments the values were significantly different. The best result of TMC value was found at the treatment dose of 9 KGy. From the present study, it was found that the fish samples treated by $9 \mathrm{KGy}$ dose contained less mold than all other treated and controlled samples and with the increase of storage time, the control 
samples obtained more mold than that of irradiated samples. Similar trend was also found from the observations of Mustafa et al. ${ }^{[7]}$, Sayed et al. ${ }^{[6]}$ and Chakraborty et $a l^{[24]}$ for different freshwater irradiated fish. So, from the total mold count it was found that $9 \mathrm{KGy}$ irradiated fish sample gave high antimicrobial efficacy.

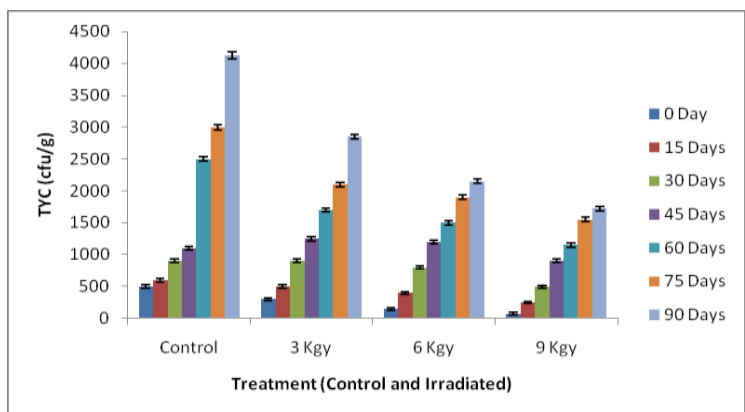

Fig. 5. Mean ( \pm SEM) TYC values in $\mathrm{cfug}^{-1}$ of Penaeus monodon at $-20^{\circ} \mathrm{C}$ with control and different doses of treatments during 90 days of storage period.

Among the treatments, the lowest TYC value was found in the $9 \mathrm{KGy}$ treatment groups whereas the highest value was measured in the control groups. The TYC of 3 KGy and 6 KGy treatments were also different. The results showed that yeast colony increased with storage period rapidly under controlled but slowly under 9 KGy treatments (Fig. 5). Since, a very few work on TYC of fresh fish has been reported in the literature, so, the results obtained from the study could not be compared widely. Mustafa et al. ${ }^{[7]}$ also found that the population was increased with the increase of storage period for Puntius sp. From the present study, it was found that the shrimps samples treated by $9 \mathrm{KGy}$ dosage contained less yeast than all other treated and controlled samples and with the increase of storage times, the control samples obtained more yeast than that of irradiated samples. So, from the total yeast count it was found that $9 \mathrm{KGy}$ irradiated shrimps sample gives the best result as preservation method. During the investigation of 90 days of storage period, Coliform and Salmonella were totally absent. Hossain et al. ${ }^{[28]}$ stated that Salmonella was absent in all (control and $150 \mathrm{Krad})$ hilsha (H. ilisha) fish samples at $5^{\circ} \mathrm{C}$ temperature storage. According to ICMSF $^{[29]}$ guideline, acceptable Salmonella for irradiated fish is absent per $25 \mathrm{~g}$ of sample. So it is unveiled that all the samples were acceptable during whole storage period.

The actual extension of shelf-life is dependent on the level of dose and the condition of fish at the time of treatment. The use of irradiation in food preservation is based on the theory that at certain dosage levels of irradiation, spoilage is prevented and pathogenic bacteria destroyed without altering the characteristics of the food. It is reported that low doses of ionizing radiation are known to reduce the spoilage causing factors in food and thereby extended the shelf-life of irradiated products ${ }^{[28]}$.

\section{CONCLUSION}

This study revealed that $9 \mathrm{KGy}$ irradiation is a good treatment for long time preservation of tiger shrimp, though it has an effect on organoleptic conditions. So, it might be effective to preserve this valuable source of foreign exchange earning shrimp with an extended shelf-life for maintaining all the international standards needed for consumer satisfaction and safety.

\section{ACKNOWLEDGEMENT}

The authors greatly acknowledged about the laboratory supports provided by Food Processing and Preservation Division, Institute of Food and Radiation Biology, Atomic Energy Commission, Savar, Dhaka.

\section{REFERENCES}

1. Nilla SS, MG Mustafa, DA Ahsan, MMR Khan and Khan MAR (2012a). Bacterial abundance in Indian white shrimp, Penaeus indicus collected from two different market conditions of Dhaka city. Dhaka Univ. J. Biol. Sci. 21(1): 29-38.

2. Nilla SS, MAR Khan, MMR Khan, DA Ahsan and Mustafa MG (2012b). Bacteriological quality of marketed mola fish, Amblypharyngodon mola from Dhaka metropolis. Bangladesh J. Zool. 40(1): 77-88.

3. DoF (Department of Fisheries) (2013). Fisheries Fortnight (Matshya Pakkahaya in Bangla) 2013. Department of Fisheries/ Ministry of Fisheries and Livestock, Dhaka. 11, 41 pp.

4. Sayed NA, MZ Alam, MMR Khan, SS Nilla and Mustafa MG (2013). Biochemical sensory and chemical changes at $-20^{\circ} \mathrm{C}$ of gamma irradiated two types of stinging catfish, Heteropneustes fossilis. World J. Zool. 8(2): 225-233.

5. Frazier CW and Westhoff CD (1988). Food Microbiology. 4th Ed. McGraw-Hill, Inc. New York. pp 109.

6. Sayed NA, MJ Alam, SS Nilla, MMR Khan and Mustafa MG (2012). Effect of gamma radiation at $-20^{\circ} \mathrm{C}$ on microbiological changes in wild and cultured stinging catfish, Heteropneustes fossilis. World J. Fish Mar. Sci. 4(6): 657-664.

7. Mustafa MG, MZ Alam, V Saha, NA Sayed, SS Nilla and Khan MMR (2013). Effects of Gamma Irradiation on Shelf-life of Preserved $\left(-20^{\circ} \mathrm{C}\right)$ Sarpunti, Puntius sarana and Thai Sarpunti, Puntius gonionotus. Jahangirnagar Univ. J. Biol. Sci. 2(1): 123-134.

8. AOAC (Association of Official Analytical Chemists) (1975). Official Method of Analysis. Association of Official Analytical Chemist. $12^{\text {th }}$ Ed. Washington DC. pp 832. 
9. Peryam DR and Piligrim FI (1957). Hedonic Assessment \& Food Technology. Food Technol. 11: 9-14.

10. Farber L and Ferro M (1956). Volatile reducing substances (VRS) and volatile nitrogen compounds in relation to spoilage in canned fish. Food Technol. 10: 303-304.

11. Sharf JM (1966). Recommended Methods for Microbiological Examination of Foods. $2^{\text {nd }}$ Edn. American Public Health Association (APHA), New York. pp 1-180.

12. BAM (Bacteriological Analytical Manual). 2005. USFDA for Detection, Enumeration and Identification of Individual Organisms. Foodinfo.net. The Netherlands.

13. Khan MAR, T Yasmin, SS Nilla, MMR Khan, N Rahman, MM Rashid and Mustafa MG (2013). Microbial occurrence in different freezing duration in speckled shrimp, Metapenaeus monoceros from Dhaka city local markets. Dhaka Univ. J. Biol. Sci. 22(2): 91-101.

14. Akintola SL, A Brown, A Bakare, OD Osowo and Bello BO (2013). Effects of hot smoking and sun drying processes on nutritional composition of giant tiger shrimp (Penaeus monodon, Fabricius, 1798). Pol. J. Food Nutr. Sci. 63(4): 227-237.

15. Nisa K and Sultana R (2010). Variation in the proximate composition of shrimp, Fenneropenaeus penicillatus at different stages of maturity. American-Eurasian J. Sci. Res. 5(4): 277-282.

16. NIN (Natural Institute of Nutrition) (1996). Nutritive Value of Indian Foods. Natural Institute of Nutrition, Icmr, Hyderabad, India. pp 32-58.

17. Begum JA and Hoque MS (1986). Effects of temperature on the composition, color, texture and reconstitution of dehydrated shrimps. Bangladesh J. Agri. Sci. 13(1): 1-4.

18. Aykroyed WR, VN Patwardhan and Ranganathan S (1951). Nutritive Value of Indian Foods and the Planning of Satisfactory Diets (Health Bulletin No.23). Manager of Publications, Govt. of India, New Delhi, India. pp 46.

19. Ferdose A and Hossain MB (2011). Nutritional value of wild, cultured and frozen prawn Macrobrachium rosenbergii (De Man, 1879). International J. Nat. Sci. 1(2):52-55.

20. Abdel-Salam HA (2013). Evaluation of nutritional quality of commercially cultured Indian white shrimp Penaeus indicus. International J. Nutr. Food Sci. 2(4): 160-166.

21. Shalini R, AR Nazar, MAB Haq and Shanker $S$ (2013). Biochemical changes of Litopenaeus vannamei and Fenneropenaeus indicus in the different stages of WSSV infection. J. Coast.
Life Med. 1(1): 63-69.

22. Puga-López D, JT Ponce-Palafox, G BarbaQuintero, MR Torres-Herrera, E RomeroBeltrán and Figueroa JLA (2013). A comparative study of physico-chemical, proximate composition and microbiological muscle properties in two species shrimps of the pacific tropical coast. J. Agric. Sci. Appl. 2(3): 151-154.

23. Nurullah M, M Kamal, MA Wahab, MN Islam, CT Ahasan and Thilsted SH (2003). Nutritional quality of some small indigenous fish species of Bangladesh. In: Small Indigenous Species of Fish in Bangladesh, eds. M.A. Wahab, S.H. Thilsted and M.E. Hoq, Technical Proc. of BAU-ENRECA/DANIDA Workshop on Potentials of Small Indigenous Species of Fish (SIS) in Aquaculture \& Rice-field Stocking for Improved Food \& Nutrition Security in Bangladesh. 30-31 October 2002, BAU, Mymensingh, Bangladesh. pp 151-158.

24. Chakraborty S, MG Mustafa, MZ Alam and Jannat M (2012). Effect of Gamma Radiation on the Sensory, Chemical and Microbiological Changes in Two Strains of Refrigerated Climbing Perch (Anabas testudineus, Bloch 1792). J. Asiat. Soc. Bangladesh Sci. 38(2): 183-188.

25. Alam MJ, MG Mustafa and Islam MM (2010). Effects of some artificial diets on the growth performance, survival rate and biomass of the fry of climbing perch, Anabas testudineus (Bloch, 1792). Nature and Science. (The United States). 8(2): 36-42.

26. Ahmed MK, M Hasan, MJ Alam, N Ahsan, MM Islam and Akter MS (2009). Effect of gamma radiation in combination with low temperature refrigeration on the chemical, microbiological and organoleptic changes in Pampus chinensis (Euphrasen, 1788). World J. Zool. 4: 09-13.

27. Haque MM, MG Sorrowar and Rashid HU (2013). Effects of frozen storage, radiation and their combined treatments on microorganisms of freshwater mola fish Amblypharyngodon Mola. J. Bangladesh Acad. Sci. 37(1): 21-31.

28. Hossain MN, N Banu, MK Hossain and Hossain MA (2001). Effect of gamma radiation on shelf-life extension of mackerel fish (Rastrelliger Kanagurta, Cuvier, 1816) at low temperature. Bangladesh J. Sci. Technol. 3(1): 167-171.

29. ICMSF (International Commission on Microbiological Specifications for Foods) (1986). Microorganisms in Foods 2: Sampling for Microbiological Analysis: Principles and Specific Applications. $2^{\text {nd }}$ ed. University of Toronto Press, Toronto. pp 181-196. 